\title{
Economic Liberties and the Original Meaning of the Constitution
}

\author{
JAMES W. ELY, JR.*
}

\section{TABLE OF CONTENTS}

I. The MERCANTILIST BACKGROUND

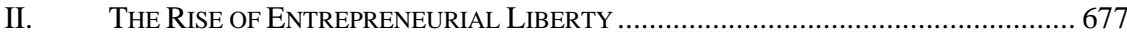

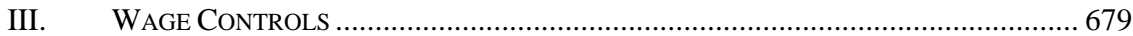

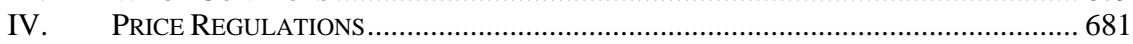

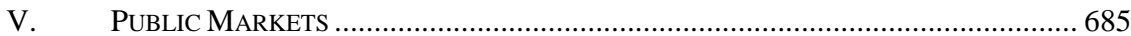

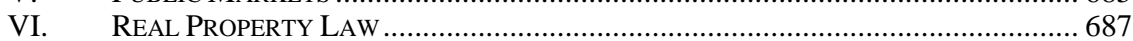

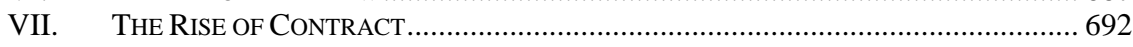

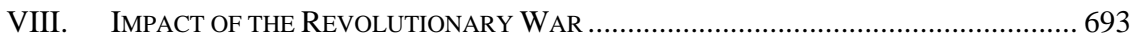

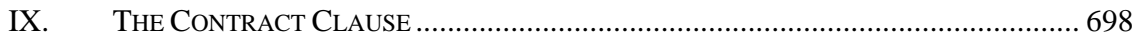

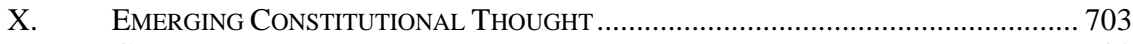

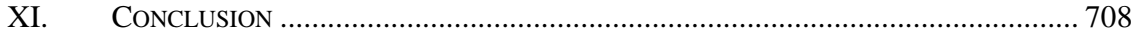

* Milton R. Underwood Professor of Law and Professor of History, Vanderbilt University. I wish to thank David E. Bernstein, Jon W. Bruce, Robert Faulkner, Scott A. Shepard, and Todd Zywicki for their insightful comments on earlier versions of this paper. I am also grateful to Stephen Jordan and Jim Kelly of the Vanderbilt University Law Library for their skill and patience in locating materials. 
It is well known that Americans of the founding era venerated the rights of property owners. Property rights were closely linked with individual liberty. ${ }^{1}$ Clearly, one of the principal objectives of the Framers was to enhance the security of private property. ${ }^{2}$

Yet the historical relationship between property rights and free market values is elusive and warrants careful exploration. How did the concept of economic liberty impact the framing of the Constitution and Bill of Rights? To what extent did the Framers embrace economic freedom and embody this concept in the Constitution? These are not easy questions to answer. ${ }^{3}$ Not only is the historical record sparse, but it is unlikely that the Framers as a group shared the same outlook. ${ }^{4}$ Moreover, economic liberty is a concept with different shades of meaning. Generalizations must be approached with caution.

Despite these caveats, in this paper I will examine the growing support for both the ideology and practice of economic liberty in the founding era. By the late eighteenth century, Americans were increasingly challenging British imperial governance, as well as long-accepted governmental regulation of the economy. I argue that by the time of the Constitutional Convention in 1787, the growing commitment to a market economy was eclipsing the older mercantilist regime as the dominant paradigm in political culture, and that this development in turn influenced the process of constitution drafting.

\section{THE MERCANTILIST BACKGROUND}

To appreciate the emergence of economic liberty, we should briefly consider the legal and economic landscape of England in the sixteenth

1. James W. Ely, JR., THE GUaRdian OF EVERY Other Right: A CONSTITUTIONAL History of Property Rights 26-58 (3d ed. 2008); John Phillip Reid, Constitutional History of the American Revolution: The AUthority of Rights 27-33 (2d ed. 1993); Walter Dellinger, The Indivisibility of Economic Rights and Personal Liberty, 2004 CATO Sup. CT. REV. 9, 19 ("Economic rights, property rights, and personal rights have been joined, appropriately, since the time of the founding.").

2. Stuart Bruchey, The Impact of Concern for the Security of Property Rights on the Legal System of the Early American Republic, 1980 WIS. L. REV. 1135, 1136 ("Perhaps the most important value of the Founding Fathers of the American constitutional period was their belief in the necessity of securing property rights.”).

3. For a discussion of the link between the Constitution and capitalism, see Bernard H. Siegan, One People As to Commercial Objects, in LIBERTY, PROPERTY, AND THE FOUNDATIONS OF THE AMERICAN CONSTITUTION 101, 101-19 (Ellen Frankel Paul \& Howard Dickman eds., 1989).

4. See Daniel A. Farber \& Suzanna Sherry, DesPerately Seeking Certainty: The Misguided Quest FOR CONSTITUTIONAL Foundations 14-16 (2002) (discussing difficulties in determining the intent of the Framers and pointing out that "the evidence of the original intent will often be fragmentary, unreliable, and conflicting”). 
and seventeenth centuries. ${ }^{5}$ Under the prevailing doctrine of mercantilism, government played an active role in regulating commerce and stimulating economic growth. ${ }^{6}$ The objective of the mercantile system was to increase national wealth by controlling the economy and securing a favorable balance of trade. $^{7}$ Mercantilism encompassed a scheme of tariffs, subsidies, grants of monopoly, and numerous regulations of private enterprise and private bargaining. ${ }^{8}$ The English colonists of the seventeenth century brought with them the legal norms and assumptions of the mother country. Although the economic conditions of North America were much different than those of England, colonial lawmakers imitated the English practice of marketplace regulation and promotion. ${ }^{9}$ Moreover, as a practical matter, the precarious existence of isolated North American Colonies in the seventeenth century reinforced the perceived need for governmental control of economic life.

A glance at the colonial statutes and ordinances of the seventeenth and early eighteenth centuries demonstrates the pervasive concern of lawmakers with economic regulation and protection of the supply of basic necessities. Following the pattern in England, the colonists sought to regulate the labor market. In addition to wage controls, there was comprehensive legislation governing slaves, indentured servants, and apprentices. Likewise, colonial lawmakers made repeated efforts to control the quality and price of goods and services. For example, the price and weight of bread was subject to widespread regulation throughout the Colonies. ${ }^{10}$ Local pricing regulations sometimes also covered meat and beer. ${ }^{11}$ Grist mills and ferryboats were treated as types of quasi-public enterprises, and tolls for their services were set by law. ${ }^{12}$ The fees of attorneys, as well as licensing requirements to practice law, were similarly fixed, a reflection

5. For a discussion of mercantilism and economic policy in England, see Richard B. MORRIS, GOVERNMENT AND LABOR IN EARLY AMERICA 1-54 (1946); Jon C. TEAFORD, THE Municipal Revolution In AMERICA 3-15 (1975).

6. MORRIS, supra note 5 , at $1-2$.

7. Id.

8. For a treatment of mercantilist ideas and actions, see LARS MAGNUSSON, MerCANTILISM: The Shaping OF AN ECONOMIC LANGUAGE 1-173 (1994); D.C. Coleman, Mercantilism Revisited, 23 Hist. J. 773, 773-91 (1980).

9. See infra notes 51-109 and accompanying text

10. See infra notes 54-81 and accompanying text.

11. See infra notes 82-90 and accompanying text.

12. LAWRENCE M. Friedman, A History OF AMERICAN LAW 38 (3d ed. 2005); Raymond E. Hayes, Business Regulation in Early Pennsylvania, 10 TEMP. L.Q. 155, 171-72 (1936). 
of popular animosity toward the legal profession. ${ }^{13}$ Laws to license and regulate peddlers were common. ${ }^{14}$ From England, the colonists adopted intensive regulation of tavern operations. ${ }^{15}$ These laws required that tavern keepers be licensed annually and fixed the charges for food, drink, and lodging. Colonial legislators widely enacted usury laws patterned after English rate ceilings to hold down the rate of interest in the hope of encouraging trade and settlement. ${ }^{16}$ Yet many Colonies set the limit higher than the prevailing rate in England in an effort to encourage investment from abroad. ${ }^{17}$ Agriculture was also subject to legislative oversight, particularly with respect to staple crops. Regulation of export trade was designed to maintain the quality of commodities, and thus to enhance the reputation of staple products from the Colonies in overseas markets. ${ }^{18}$ The Maryland and Virginia legislatures, for instance, imposed controls on the production and sale of tobacco, and sought to halt the export of unsound tobacco. ${ }^{19}$ Pennsylvania enacted numerous laws governing the export of wheat, flour, and meat. ${ }^{20}$ Similarly, South Carolina regulated shipments of indigo abroad. ${ }^{21}$ This sketch of colonial economic regulations is far from complete, but it does suggest a commitment to mercantilist policies and a distrust of economic liberty and open competition.

My focus is upon colonial market regulations, but it is important to bear in mind that the colonial economy developed under the auspices of the British imperial system. Mercantilist theory held that Colonies existed primarily to benefit the mother country. ${ }^{22}$ For much of the seventeenth century, however, England largely ignored the fledgling North American Colonies. This period of neglect changed following the Stuart Restoration. ${ }^{23}$ Parliament imposed new controls designed to bind the Colonies more

13. Charles WARren, A History of the American Bar 41-42, 53, 112 (1911).

14. Hayes, supra note 12, at 169.

15. See infra note 32 and accompanying text.

16. James M. Ackerman, Interest Rates and the Law: A History of Usury, 1981 ARIZ. ST. L.J. 61, 85.

17. Id.

18. FrIEDMAN, supra note 12, at 40-41 (discussing colonial efforts "to keep . . . staple crops under some kind of quality control”); Hayes, supra note 12, at 161-62 (discussing export controls designed to maintain Pennsylvania's reputation abroad).

19. FRIEDMAN, supra note 12, at 40.

20. Hayes, supra note 12, at 159-62.

21. ELY, supra note 1, at 21.

22. Kermit L. Hall \& Peter Karsten, The Magic Mirror: Law in American HISTORY 43 (2d ed. 2009).

23. For the impact of the Restoration on the Colonies, see generally WESLEY Frank Craven, The Colonies in Transition, 1660-1713, at 1-103 (1968). 
closely within the imperial framework. ${ }^{24}$ The Navigation Acts sharply curtailed freedom of trade by requiring that goods imported to the Colonies must pass through England. ${ }^{25}$ Because direct importation from continental Europe was prohibited, the manufactured goods purchased by the colonists were largely made in England. Further, most raw materials exported from the Colonies could be shipped only to England. ${ }^{26}$ Although these trade restrictions gave the Colonies privileged access to the English market, they made the Colonies dependent on the mother country for manufactured goods. Over time, the Navigation Acts shackled colonial economic ambitions and engendered ill-feeling toward England. ${ }^{27}$ One goal of the American Revolution was to overthrow these controls on the colonial economy and achieve economic independence. "It was a commercial restriction which caused the revolution," the Pennsylvania Supreme Court recalled in 1853, "and injuries to our trade which produced the subsequent war against England . . ..,28

On paper, at least, many facets of colonial economic life appear to have been closely regulated. One would certainly be hard pressed to picture colonial Americans as adherents of a strict laissez-faire philosophy. Indeed, several scholars have suggested that colonial economic controls anticipated later New Deal regulatory programs. ${ }^{29}$

\section{THE RISE OF ENTREPRENEURIAL LIBERTY}

How, then, can one maintain that the founding generation valued economic liberty? Several factors point in this direction. We should start by stressing the living law rather than focusing on a list of legislative rules. There is room to doubt the efficacy of colonial regulatory measures. Colonial governments were feeble institutions that

24. HALL \& KARSTEN, supra note 22, at 18 (observing that "the restored Stuart monarchy in England wished to knit the colonists more fully into the fabric of the empire").

25. Oliver M. Dickerson, The Navigation Acts and the American Revolution 7-9 (1951).

26. For the operation of the Navigation Acts, see DICKERSON, supra note 25, at 3 30; Craven, supra note 23, at 33-37; Nuala Zahedieh, Making Mercantilism Work: London Merchants and Atlantic Trade in the Seventeenth Century, 9 TRANSACTIONS ROYAL HIST. SOC’y (6th ser.) 143, 144 (1999).

27. ELY, supra note 1, at 18-19.

28. Sharpless v. Mayor of Phila., 21 Pa. 147, 170 (1853).

29. See FrIEDMAN, supra note 12, at 40 (suggesting that colonial regulation of staple crops foreshadowed New Deal farm programs); Hayes, supra note 12, at 155 (tracing regulations of New Deal era to Pennsylvania colonial laws). 
lacked a strong revenue base and supervisory officials. It followed that enforcement mechanisms were lax and compliance with controls often limited. ${ }^{30}$ A few examples illustrate the gap between legislative policy and economic reality. Usury laws were easily evaded and likely had little impact on ordinary credit relationships. ${ }^{31}$ Tavern regulations are another case in point. One scholar declared: "Taverns are clearly the number one exhibit in early America of a local business regulated by government. . ..”32 Nonetheless, Virginia tavern regulations were widely ignored, and local officials did little in response to chronic complaints about overcharging. ${ }^{33}$ The very fact that legislators so frequently altered and amended regulatory legislation gives rise to an inference that prior controls had proven ineffective. ${ }^{34}$ In sum, a focus solely on the formal law may yield a false measure of the amount of economic liberty in the colonial world.

Aside from regulatory failure, larger economic trends strengthened colonial receptivity to greater market freedoms by the late eighteenth century. During the eighteenth century, the Colonies experienced rapid population growth, economic expansion, and an increase in the standard of living. ${ }^{35}$ As the Colonies matured and grew prosperous, the perceived need for comprehensive economic regulations gradually lapsed. A flourishing Atlantic trade brought ever more colonists into a market economy. ${ }^{36}$ In a world increasingly shaped by opportunity rather than

30. FRIEDMAN, supra note 12, at 39 (“[T] he people who ran the colonies had very little in the way of tax money, or staff, at their disposal.”).

31. HENRY W. FARNAM, CHAPTERS IN THE History OF SOCIAL LEGISLATION IN THE UNited StATES TO 1860, at 88-91 (1938); Ackerman, supra note 16, at 61, 85 (noting that colonial usury laws "seem to have been widely evaded").

32. Paton Yoder, Tavern Regulation in Virginia: Rationale and Reality, $87 \mathrm{VA}$. MAG. Hist. \& BIO. 259, 273 (1979); see also MORRIS, supra note 5, at 21 ("In the Southern colonies the setting of tavern rates was the most consistent example of price regulation undertaken by the county or sessions courts right through the Revolutionary period.”).

33. Yoder, supra note 32, at 266-78 (noting numerous complaints about illegal rates as well as lapses in the licensing process); HALL \& KARSTEN, supra note 22, at 42 (pointing out that local officials often ignored tavern regulations "they perceived as unimportant or unenforceable”).

34. E.A.J. JOHNSON, AMERICAN ECONOMIC THOUght IN THE SEVENTEENTH CENTURY 142-43 (photo. reprint 1961) (1932) ("Very often [economic regulations] failed in their purpose; in fact, the necessity of their re-inactment [sic] is proof of their evasion.”).

35. Marc Egnal, The Economic Development of the Thirteen Continental Colonies, 1720 to 1775, 32 WM. \& MARY Q. 191-222 (1975). See also GORDON S. WoOd, THE RADICALISM OF THE AMERICAN REVOLUTION 169 (1991) (pointing out that in the colonial world of the 1760s and 1770s, "[f]or most white Americans there was greater prosperity than anywhere else in the world”).

36. Joyce Appleby, Capitalism and a New Social Order: The Republican VISION OF THE 1790s, at 40-41 (1984). 
scarcity, many colonists relied on individual initiative and private bargaining, and saw the regulatory regimes of the past-both imperial and domestic - as an impediment to their economic ambitions. ${ }^{37}$

Of course, this change of attitude did not occur abruptly, but the impact of the new outlook was clear by the time of the founding. At first, few questioned the right of government to control economic activities, but many increasingly doubted the wisdom of such regulations. In time, however, some took the next step and challenged the authority of government to supervise economic exchanges in a free market. To trace this evolution, let us consider several aspects of the colonial economy.

\section{WAGE CONTROLS}

The origins of wage regulation in the Colonies can be found in the English Statute of Laborers (1350) and the Statute of Artificers (1563). ${ }^{38}$ The first of these measures, passed in response to the labor shortage caused by the Black Death, sought to compel work at pre-plague wages. ${ }^{39}$ This legislation was replaced by the Statute of Artificers, under which justices of the peace were empowered to determine wages annually for each county. ${ }^{40}$ It bears emphasis that these laws were framed in large part to hold down wages. ${ }^{41}$ Thus, employment relationships in the English tradition were governed by regulatory regimes rather than contracts between employers and workers. ${ }^{42}$ This reflected lingering medieval notions of a static society in which one's place was fixed by birth and status.

The English policy of regulating wages was transported to the Colonies. Throughout much of the seventeenth century, the Coloniesespecially in New England-experimented with wage controls. ${ }^{43}$ There was initially no objection to the principle of wage regulation. ${ }^{44}$ Conditions in colonial America, however, were radically different than in England, and did much to undermine wage controls. The bulk of the

37. Id. at 28-39.

38. John V. Orth, Contract and the Common Law, in The State And Freedom of ConTRACT 44, 50-53 (Harry N. Scheiber ed., 1998).

39. Id.

40. Id. at 51.

41. Id.; see also MoRRIS, supra note 5, at 19.

42. Orth, supra note 38, at 50-51.

43. MORRIS, supra note 5, at 55-91; FARNAM, supra note 31, at 57-60.

44. Id. 
labor force consisted of self-employed farmers. ${ }^{45}$ Relatively few people worked for wages, and they could in most cases easily obtain land of their own. ${ }^{46}$ Free labor was therefore both scarce and mobile. The chronic shortage of labor explains the heavy colonial reliance on an unfree work force composed of slaves, convicts, and indentured servants, but it also rendered futile legislative attempts to cap wages for free labor. Market pressures simply drove wages higher despite statutory ceilings. Historians agree that efforts to limit the cost of labor in the colonial era were a failure. Lawrence M. Friedman has aptly noted: "Wage-price regulation was virtually abandoned by $1700 .{ }^{\prime 47}$

In its place there developed a system of labor relations in which wages were determined by market forces and bargaining. Earlier wage regulations were either repealed or ignored. In their study of wage controls in Massachusetts, Richard M. Morris and Jonathan Grossman concluded:

But all signs point to the disintegration in the eighteenth century of the general scheme of wage-fixing in Massachusetts, despite the fact that the basic system embodied in the Codes of 1648 and 1660 remained on the law books unrepealed. The absence of extensive regulatory codes, considered in conjunction with other factors, is evidence of the breakdown of mercantilism as a system of internal regulation and of the rise of laissez-faire practices in industry and commerce considerably before the Revolution. ${ }^{48}$

By the end of the seventeenth century, the intermittent interest in wage controls withered in other Colonies as well. ${ }^{49}$

Notwithstanding archaic wage controls embodied in law, in reality a wage labor market grounded on contracts emerged by the eve of the Revolution. Individuals were free to pursue their own interests and to bargain over wages. One prominent scholar observed: "In colonial times, in areas or during periods in which the regulation of wages was not a matter of public concern, the wage rate was determined by a bargain between employer and employee." 50 Thus, the law of employment was transformed by the collapse of wage regulation and the growth of free contract ideas.

45. Egnal, supra note 35, at 200-01 ("Farming was the most important colonial occupation, and was the chief employment of between 80 and 90 percent of the working population.”).

46. FARNAM, supra note 31, at 57 ("The people who worked for wages were not numerous enough to constitute an important class, and the ease with which land could be obtained, as well as the great difficulty of obtaining labor in a new country, made them independent.").

47. FRIEDMAN, supra note 12, at 43.

48. Richard B. Morris \& Jonathan Grossman, The Regulation of Wages in Early Massachusetts, 11 NEw ENG. Q. 470, 498 (1938).

49. FRIEDMAN, supra note 12, at 43.

50. MORRIS, supra note 5, at 208. 


\section{PRice Regulations}

Colonial lawmakers also adopted pervasive schemes of price regulation, covering the sale of a wide range of products. Such legislation harked back to the medieval notion of a just price, under which considerations of fairness and customary pricing could trump the right to charge market prices. $^{51}$ Price controls reflected thinking molded by an economy of scarcity.

The story of colonial price regulations is more complex than that of wage controls. Not only did pricing controls reach a large variety of commodities, but price regulations persisted longer than those governing wages. $^{52}$ As late as 1763, for example, the Common Council of New York City enacted a detailed schedule setting "reasonable prices for all sorts of Victuals." ${ }^{53}$ In short, attempts to fix prices did not collapse as abruptly as the efforts to hold down wages. Nonetheless, by the late eighteenth century, the ideology of economic liberty made steady inroads on price fixing regimes. I will examine this process by concentrating on regulations dealing with the price of bread and meat.

No transaction was regulated more closely and for a longer time than the sale of bread. Following the practice in England, colonial localities from Boston to Charleston were typically authorized to establish the assize of bread during the seventeenth and eighteenth centuries. ${ }^{54}$ Under the assize, the price and weight of bread was fixed in accordance with the price of flour. ${ }^{55}$ The set price varied for different kinds of bread. ${ }^{56}$ Bakers were required to mark their bread, and those who failed to meet the weight and price specifications were subject to a fine and seizure of their bread. ${ }^{57}$ The purpose behind the assize of bread was to protect the

51. JoHNSON, supra note 34, at 123, 139, 221

52. Still, it is noteworthy that efforts of colonial officials in Virginia to limit trade and set maximum prices were unpopular and controversial in the seventeenth century. William E. Nelson, Authority and the Rule of Law in Early Virginia, 29 OHIO N.U. L. REV. 305, 355-57 (2003).

53. Thomas F. DeVoe, The Market Book: A History of the Public Markets IN THE CiTY OF NEW YORK 140 (photo. reprint 1969) (1862).

54. For the assize of bread, see generally FARNAM, supra note 31, at 107-12; see also MorRIS, supra note 5, at 161-66; 1 WILliAM G. PANSCHAR, BAKING IN AMERICA: ECONOMIC DEVELOPMENT 26-27 (1956).

55. FARNAM, supra note 31 , at 107-12.

56. Id.

57. Id. 
public from the perceived abuses of bakers. The New Hampshire legislature explained in 1766 that the assize was needed because

a just Proportion between the Price of Flour and the Weight and Price of Bread is now a Matter of Importance as many People purchase the greatest part of their Bread of Bakers and without such Regulation they are left to Judge for themselves where their Impartiality will be much Questioned $\ldots .58$

As this statutory language suggests, the assize was usually justified in terms of greedy bakers and vulnerable customers.

As might be expected, efforts to enforce the assize of bread proved difficult. Starting in the early seventeenth century, bakers often protested, arguing that the set price was inadequate and that they should receive greater return for their labor. Philadelphia bakers in 1751 asked to be freed from the assize of bread. ${ }^{59}$ Bakers succeeded from time to time in obtaining upward adjusted prices for bread. ${ }^{60}$ To add muscle to their complaints, bakers periodically resorted to strikes. As early as 1659, bakers in New York City refused to bake until local officials raised the prices for bread. ${ }^{61}$ There was also a short-lived work stoppage in $1741 .{ }^{62}$ Likewise, bakers in Charleston stopped baking in November of 1786, complaining about an insufficient price under the assize. ${ }^{63}$ Nor were consumers entirely happy. There were frequent charges that bakers were ignoring the assize and charging market prices. Clearly, the assize of bread had become highly contentious by the end of the eighteenth century. $^{64}$

Bakers increasingly demanded not just higher price schedules but an end to municipal regulation of prices. ${ }^{65}$ As the ideology of economic liberty gained ground, the days of the assize of bread were numbered. Baltimore and New Haven decided not to control the price of breadstuffs. ${ }^{66}$ In December of 1792, Philadelphia and Boston bakers petitioned the legislatures of Pennsylvania and Massachusetts to end regulations on the

58. An Act to Regulate the Price \& Assize of Bread, 6 Geo. 111. Orig. Acts, vol. 5, p. 83; recorded Acts, vol. 3, p. 11; N.H. Province Laws 387 (enacted Jan. 16, 1766).

59. 1 J. ThOmas Scharf \& Thompson Westcott, History of Philadelphia, 1609-1884, at 245 (1884).

60. MORRIS, supra note 5, at 161-62.

61. Id.

62. Id. at $162-65$.

63. Leila Sellers, Charleston Business on the Eve of the American REVOLUTION 23-24 (1934).

64. MORRIS, supra note 5, at 161 ("Relations between the public authorities and the bakers were frequently tense, and at times culminated in actual strikes of master workers.”).

65. TEAFORD, supra note 5, at 94-95.

66. Id. 
price and size of bread. ${ }^{67}$ They argued that competition would better set prices than any assize. ${ }^{68}$ After consideration, the Pennsylvania legislature in 1793 suspended the assize of bread. The lawmakers noted concerns about whether the assize "infringe[d] the equality of rights established by the constitution of this commonwealth." 69 Four years later the assize law was repealed, marking an end to bread price regulations in Pennsylvania. ${ }^{70}$ One scholar concluded that in Pennsylvania, "it was then deemed unconstitutional for the state to limit prices" aside from monopolies. ${ }^{71}$

The campaign to eliminate the assize of bread in New York City is especially illuminating. By the 1790s, bakers were petitioning the common council, not simply to adjust bread prices, but to end regulation altogether. ${ }^{72}$ "Influenced by the burgeoning capitalist economy and freer economic attitudes of the early national period," one scholar has maintained, "they deemed it grossly unfair for their profession to be singled out for income limitation." ${ }^{73}$ In 1800, the city responded to this demand by abolishing bread price regulations. ${ }^{74}$ A decision by the common council to reinstitute the assize in October of 1801 prompted a work stoppage by the angry bakers. ${ }^{75}$ An attempt by investors to organize a corporate bread enterprise-The Bread Company — added to the controversy. ${ }^{76}$ What is striking, however, is the extent to which the idea of economic liberty was at the center of the ensuing debate. One defender of The Bread Company insisted: "No mechanic should be restricted in his profits by any power-it is

67. Dunlap’s American Daily Advertiser, April 4, 1793; Richard C. Bull, The Constitutional Significance of Early Pennsylvania Price-Fixing Legislation, 11 TEMP. L.Q. 314, 318-19 (1937).

68. Id.

69. Act of Sept. 4, 1793, ch. 1702, 14 The Statutes at LaRge Of Pennsylvania FROM 1682 TO 1801, at 510 (James T. Mitchell \& Henry Flanders eds., 1909).

70. Act of Apr. 1, 1797, ch. 1947, 15 The StatuTES at LARGE OF PenNsylvania FROM 1682 TO 1801, at 510 (James T. Mitchell \& Henry Flanders eds., 1911).

71. Bull, supra note 67, at 319.

72. Howard B. Rock, The Perils of Laissez-Faire: The Aftermath of the New York Bakers' Strike of 1801, 17 LAB. HIST. 372, 374-75 (1976). The New York bakers protested repeatedly during the 1790s that the price of flour and the wages of employees had risen considerably while the price of bread was limited. Petitions of Bakers (Jan. 20, 1789, Nov. 4, 1792, June 22, 1793, Mar. 25, 1795) (on file with author and on file with the New York City Department of Records and Information Services).

73. Rock, supra note 72, at 374 .

74. Id. at 375 .

75. Id. at 376 .

76. Id. at 378-85. 
fundamentally contrary to every principle of Justice, and it strikes at the root of industry." 77 The Bread Company failed, and the bakers continued to press for repeal of the assize. ${ }^{78}$ Individual bakers, invoking free market principles, occasionally defied the municipal regulations. ${ }^{79}$ In 1821, New York City finally abandoned price controls on bread. ${ }^{80}$ Although a hardy survivor of mercantilist policy, the assize was a belated casualty of new economic thought. ${ }^{81}$

The cost of meat was also controlled from time to time, but not with the same regularity as bread. There is evidence that attempts to fix the price of meat ran into the same combination of practical and philosophical objections that undercut the assize of bread. Consider the experience of New York City. In 1763, toward the end of the French and Indian War, there were complaints about the high cost of commodities and calls for price regulation. ${ }^{82}$ In response, the common council attributed the high prices to "the avarice" of suppliers. ${ }^{83}$ It set a schedule of "reasonable prices" for a wide variety of meat and fish, including beef, pork, veal, lamb, and chicken, all sold in the public market. ${ }^{84}$ Farmers and butchers were outraged by these price regulations. ${ }^{85}$ Many halted meat sales in the city, and offered to sell provisions at points outside municipal jurisdiction. $^{86}$

But the most salient aspect of this controversy for our purposes was the explicit appeal to principles of economic freedom as a basis to challenge price controls. Describing themselves as "friends to the liberty of Englishmen," a number of farmers and butchers boldly asserted: "We thought we were born free Englishmen, and had the liberty, as such, to sell our own effects at our own liberty." ${ }^{87}$ Moreover, some butchers openly defied the law and sold at market prices. ${ }^{88}$ Reflecting a gradual shift in attitude, the butchers now called for a free market in provisions. ${ }^{89}$

77. Id. at 384 .

78. Id. at 385 .

79. Id. at 385-86.

80. Id. at 387.

81. Id. at 384; see also PANSCHAR, supra note 54, at 27 (pointing out that "the bread laws became less severe both in scope and impact as the 18th century drew to a close," and asserting that "a growing spirit of free competition tended to make such measures obsolete").

82. DeVoe, supra note 53, at 139-40.

83. Id. at 140 .

84. Id. at $140-45$.

85. Id. at 145.

86. Id. at 145-47.

87. Id. at 147 .

88. Id. at 148-49.

89. Id. at 149-50. 
Following a familiar pattern, city officials found a temporary solution by raising the set prices of meat to appease the butchers. ${ }^{90}$

\section{PUBlic MARKETS}

Closely allied to price regulation was the establishment of public markets in colonial cities. ${ }^{91}$ Drawing upon long-settled English practice, lawmakers sought to organize and control private trading. As one scholar noted, "Farmers entering the larger towns encountered regulations which considerably abridged their freedom of marketing ....,92 Market regulations prescribed the time and place for trade, banned buying and selling outside the market, and mandated the use of standard weights and measures. Thus, all sellers and prospective purchasers were brought together in one place. The clerk of the market supervised operations, sought to maintain quality control of commodities sold in the market, and endeavored to eliminate fraudulent practices. ${ }^{93}$ Municipalities rented stalls in the market to sellers. ${ }^{94}$ To protect this regulated market, municipalities commonly legislated against forestalling and engrossing. Forestalling was the practice of purchasing commodities on the way to market with the intention of reselling at a higher price. The practice of engrossing was the purchase of a large amount of a particular commodity in the hope of increasing its price above the market level. ${ }^{95}$ It was thought that such activities raised prices without providing a service and that they threatened to monopolize the supply of commodities. ${ }^{96}$ The purpose of establishing public markets was to provide the urban population

90. Id.; see also MAX GeOrge Schumacher, THE NORTHERn FARMER AND His MARKets During the LATE COlONIAL PERIOD 136-38 (1975) (discussing the failed attempt to set a comprehensive list of food prices for New York City in 1763, and pointing out that "the idea of just price clashed with the rising doctrine of the free market").

91. For a discussion of public markets in the colonial era, see CARL BRIDENBAUGH, Cities In the Wilderness: THE FIRST CentURy of URBAN LifE IN AMERICA 1652-1742, at 192-95, 349-53 (1938); FARNAM, supra note 31, at 77-80; ERNEST S. GRIFFITH, History of American City Government: The Colonial Period 144-52 (1938); J.R.T. Hughes, Social Control In THE Colonial ECONOMY 126-27 (1976); SELlers, supra note 63, at 21-23; TEAFORD, supra note 5, at 39-43, 51-52.

92. SCHUMACHER, supra note 90 , at 91.

93. James W. Ely, Jr., Patterns of Statutory Enactment in South Carolina, 1720 1770, in South Carolina Legal History 69 (Herbert A. Johnson ed., 1980) (discussing public market regulations in Charleston).

94. BRIDENBAUGH, supra note 91, at 349-50.

95. TEAFORD, supra note 5, at 9-10.

96. SCHUMACHER, supra note 90, at 93-94. 
with equal access to reasonably priced food and other necessities. ${ }^{97}$ Public supervision, not free trade by individuals, was the key characteristic of these regulated markets.

Yet during the eighteenth century there was mounting criticism directed against municipal controls on buying and selling. Legislative language about the need for regulated markets did not match reality. The imposition of market regulations never eliminated all private trading elsewhere. $^{98}$ Many farmers and traders preferred private marketing, under which they could sell to customers at competitive prices. ${ }^{99}$ Complaints about higher prices as a result of forestalling and engrossing were frequent. Indeed, it appears that the law against forestalling was frequently ignored. ${ }^{100}$

Moreover, there was a growing sense of skepticism about the supposed advantages of public markets. Strong resistance to the establishment of a public market appeared in Boston. ${ }^{01}$ Not only did Bostonians worry that regulated markets would drive trade to other towns, but they expressed concern that such controls constituted "a breach upon their natural rights and liberties." ${ }^{\text {"102 }}$ Persistent opposition doomed Boston's efforts to maintain a public market system. In 1737, a riotous mob destroyed the municipal market houses. ${ }^{103}$ Pressure mounted in the 1740 s against public markets and commodity price fixing in Massachusetts. ${ }^{104}$ In the 1760s, Bostonians continued to argue that market controls should "not deprive us of the liberty common to Englishmen.”105

Boston's staunch resistance to public markets was unique in the colonial era. A number of other cities, from Philadelphia to Charleston,

97. FARNAM, supra note 31, at 80 ("The colonial laws which established markets and fairs were an attempt to organize trade in a general way, so as to assure to all the people a fair chance to satisfy their needs.”); GARY B. NASH, THE URBAN CRUCIBLE: Social Change, Political Consciousness and the ORIgins of the AMERICAN REVOLUTION 129-30 (1979) (pointing out that the idea behind public markets was to make farm produce available to urban workers at reasonable prices).

98. SCHUMACHER, supra note 90, at 94 (observing "that the measures to restrict retailers and to concentrate marketing were very frequently violated is clear").

99. NASH, supra note 97, at 130-31.

100. There were persistent complaints about forestalling and engrossing. CARL Bridenbaugh, Cities in Revolt: URBAN Life in AMERICA, 1743-1776, at 82 (1955); SCHUMACHER, supra note 90, at 94; G.B. WARDEN, Boston 1689-1776, at 116 (1970).

101. TEAFORD, supra note 5, at 40-41.

102. Id. at 41; see also WARDEN, supra note 100, at 53 ("The establishment of market regulations in itself implied a serious threat to the Bostonians' freedom of economic opportunity.”).

103. NASH, supra note 97, at 130-35; WARDEN, supra note 100, at 118-23.

104. Winifred BARR ROTHENBERG, From MARKET-Places tO A MARKET Economy: The Transformation of RuRAL MAsSACHUSETTS, 1750-1850, at 98-99 (1992).

105. TeAford, supra note 5, at 43 (quoting Boston Evening Post, Sept. 12, 1763). 
adopted the public market system. ${ }^{106}$ In 1763, as part of a comprehensive price-fixing scheme, New York City prohibited all selling of many food items outside the established market. ${ }^{107}$ Yet effective enforcement of the market laws varied widely, and these regulations likely remained on the books long after they had become a dead letter. One historian persuasively concluded:

The elaborate and detailed regulations which these incursions into economic control entailed were never fully successful, even in their heyday. By 1750 they gave very definite indications of cracking under the strain of the mobility and stir which had begun to characterize the urban centres of Philadelphia and New York. 108

By the eve of the Revolution, he added, "markets were no longer exclusive," and "only the hollow shell of limited trade regulation remained."109 The entrepreneurial spirit had prevailed over mercantilist attachment to controlled markets.

\section{REAL PROPERTY LAW}

In assessing economic controls in colonial America, historians have concentrated upon commercial activity in urban centers. But colonial life was predominantly rural in character. "Farming was the most important colonial occupation," one study stressed, "and was the chief employment of between 80 and 90 percent of the working population." 110 The prospect of acquiring land was one of the main inducements for colonists to settle in North America. ${ }^{111}$ Given the availability of land, the vast majority of farmers owned land. ${ }^{112}$ The law of real property was central to colonial society in which land represented the primary source of wealth. Any account of the growth of economic liberty, therefore, must take account of the law governing real property.

106. BRIDENBAUGH, supra note 91 , at 349-52.

107. DEVOE, supra note 53, at 140-45.

108. GRIFFITH, supra note 91, at 129.

109. Id. at 160; see also HUGHES, supra note 91, at 131 (observing that the system of controlled markets "largely passed into history even before the end of the colonial era").

110. Egnal, supra note 35, at 200-01.

111. ELY, supra note 1, at 10-11.

112. WoOD, supra note 35, at 123 (“[M]ost American farmers owned their land.”). 
English land law provided the basis for colonial landownership. ${ }^{113}$ In England, land was the preeminent basis of wealth and social status, and consequently rules governing inheritance were central to English land law. ${ }^{114}$ English law showed a strong preference for maintaining the cohesiveness of landed estates over generations. The most striking expression of this policy was the doctrine of primogeniture, under which all land in cases of intestacy passed to the eldest male heir. ${ }^{115}$ This meant that the estate would remain intact as one parcel. Closely related to primogeniture was the practice of entailing estates. ${ }^{116}$ A landowner could provide by conveyance that an estate should descend through the family line forever. ${ }^{117}$ Thereafter, the owner in each generation obtained what amounted to only a life interest in the property. English law also protected landed estates from seizure by creditors. ${ }^{118}$ This system shielded landholding elite from the hazards of enterprise and the vicissitudes of a market economy.

Conditions in North America, however, were very different from those in England, and the traditional treatment of land was ill-suited to the colonial experience. Land was scarce in England but abundant in North America. Ownership of land was far more widespread than in England. A 1777 pamphlet boasted that Americans were "a people of property; almost every man is a freeholder." transformation of property law during the colonial era. Land law reform had two primary goals: to overhaul rules of inheritance and to foster the free alienability of land. Both objectives reflected the desire to reshape land law in ways consistent with the principle of economic liberty.

The New England Colonies started the process of dismantling the traditional inheritance laws in the seventeenth century. Primogeniture was deeply unpopular as a symbol of the aristocratic land order of England. ${ }^{120}$ New Englanders rejected primogeniture in favor of partible inheritance with an equal distribution of property among children upon

113. Richard B. Morris, Studies in the History of American LAW 73-75

(1930). For the English background of colonial land law, see id. at 69-125.

114. FRIEDMAN, supra note 12, at 24.

115. MORRIS, supra note 113, at 73-81.

116. John V. Orth, After the Revolution: "Reform" of the Law of Inheritance, 10 LAW \& HisT. REV. 33 (1992).

117. Id.

118. See infra notes $132-139$ and accompanying text.

119. WoOD, supra note 35, at 234 (quoting PA. PACKET, Nov. 26, 1776; S.C. \& AM. GAZETTE, Nov. 6, 1777).

120. Stanley N. Katz, Republicanism and the Law of Inheritance in the American Revolutionary Era, 76 MiCH. L. REV. 1, 11 (1977) ("For the Revolutionary generation, the law of inheritance took on a new, strategic importance, since it appeared to symbolize the aristocratic aspects of English government against which the Revolution increasingly directed itself.”). 
death. ${ }^{121}$ Pennsylvania followed suit. ${ }^{122}$ Primogeniture and entail existed elsewhere in colonial America but were of declining importance. ${ }^{123}$ Because colonists had the right to dispose of land by will, landowners could readily circumvent primogeniture. ${ }^{124}$ Entailed estates were impractical because they could not be sold or used as the basis for credit. Thus, the practice of entailing stalled economic development. ${ }^{125}$ Most states abolished primogeniture and the fee tail estate at the time of the American Revolution. ${ }^{126}$ Holdings in fee tail generally were converted into fee simple estates. ${ }^{127}$ This change strengthened the rights of current owners, who could now transfer the property or incur debts based on their holdings. In short, the abolition of primogeniture and entail promoted freedom of testamentary disposition and was consistent with a marketbased concept of property. Rather than inspiring these changes, the Revolution ratified a reform process already underway in the Colonies.

This sweeping revision of inheritance law reflected new currents of thought regarding property. ${ }^{128}$ First, land should be distributed equally in intestacy. Hence, the elimination of primogeniture encouraged a wide distribution of a decedent's property. Second, land was valued for what profits it could produce, not as a permanent seat of family social position and political power. Entailed estates made no sense in a society that treated land as a commodity and in which land speculation and sales on the open market were frequent.

121. George L. Haskins, The Beginnings of Partible Inheritance in the American Colonies, 51 YALE L.J. 1280, 1280 (1942).

122. Id. at $1280-81$.

123. Historians have debated the extent to which primogeniture and entailing were used in different colonies. See Katz, supra note 120, at 13 ("Primogeniture did not exist in many of the colonies, especially in New England, prior to the Revolution, and it is not clear that the use of either primogeniture or entail to restrict the distribution of property was widespread.”); C. Ray Keim, Primogeniture and Entail in Colonial Virginia, 25 WM. \& MARY Q. 545 (1968).

124. FRIEDMAN, supra note 12, at 30 (pointing out that primogeniture applied only to intestate estates, and that landowners could make other arrangements by will).

125. Keim, supra note 123, at 585 (concluding that entailed estates prevented land speculation and constituted a barrier to obtaining a mortgage or credit).

126. FARNAM, supra note 31, at 51-53; Katz, supra note 120, at 11-14; Orth, supra note 116 , at 33 .

127. Katz, supra note 120, at 15 (pointing out that the North Carolina legislature changed holdings in fee tail to fee simple); MorRIS, supra note 113, at 92-93 (noting that most states made the fee tail a fee simple).

128. Katz, supra note 120, at 11-29. 
Allied to revision of inheritance law was the move to facilitate the transfer of land. The colonists developed practices to simplify land transactions. Foremost among these was the system of recording land titles. New Englanders established public recordation in the seventeenth century. ${ }^{129}$ The recordation scheme helped to eliminate confusion and dispute over land titles and thus encouraged a market for the purchase and sale of land. ${ }^{130}$ As one historian has noted, rules requiring "inventory of estates and recording of land transfers were explicitly designed to promote the rise of market capitalism by clarifying who owned what and thereby rendering ownership of property secure." ${ }^{31}$ At the same time, the colonists streamlined deeds and modified the complicated English legal procedures to determine ownership.

Some Colonies also began to modify the English law that protected land from the claims of creditors. A desire to attract credit from English merchants prompted these steps. ${ }^{132}$ In 1700 , for example, the Pennsylvania legislature enacted a measure which made all the land of a debtor liable for debts. ${ }^{133}$ In the late seventeenth and early eighteenth centuries, several New England Colonies authorized creditors to take land to satisfy obligations. ${ }^{134}$

Parliament hastened the process of eliminating the traditional real property exemption from claims of the creditors in the Colonies with passage of the Act for the More Easy Recovery of Debts in 1732. ${ }^{135}$ Reflecting concern by British creditors that colonists were relying on English law to frustrate collection of debts, the Act declared that all types of property in the Colonies were liable to satisfy debts. ${ }^{136}$ They applied to all debts, not just obligations owed to British creditors. ${ }^{137}$ As a practical matter, the Act likely enlarged the market for land both by judicial sale of debtors' property and by debtors' voluntary sales to satisfy creditors' claims. Most states adhered to the policy of making land subject to creditors after the Revolution. ${ }^{138}$ Claire Priest cogently concluded: "Another important consequence of the Debt Recovery Act was to expand the commodification of land. Streamlining the procedures

129. FRIEDMAN, supra note 12, at 27.

130. Id. ("But in a new place, where land was a commodity, recording seemed necessary - an important tool of the volatile, broadly based land market.”).

131. Nelson, supra note 52, at 359.

132. Claire Priest, Creating an American Property Law: Alienability and Its Limits in American History, 120 HARV. L. REV. 385, 411 (2006).

133. Id. at 412 .

134. Id. at $408-16$.

135. 1732, 5 Geo. 2, c. 7 (Eng.).

136. Priest, supra note 132, at 423-24.

137. Id. at 424.

138. Priest, supra note 132, at 439-47. 
associated with the sale of land by execution made it easier and less costly for both unsecured and secured creditors to seize land.”139

By the founding era, land was treated as a market commodity. "Family farms," Gordon S. Wood declared, "were now thought of less as patrimonies and more as commodities."140 Not only was there a large market for land, but speculation in undeveloped land was common. Both elite figures and ordinary farmers saw speculation as a path to wealth. ${ }^{141}$ “America," one scholar observed, "witnessed a veritable land frenzy in the post-Revolutionary period. Eighteenth century Americans knew that land speculation could be very profitable, and thus nearly every segment of society, from the lowly squatter to the largest land baron, engaged in the buying and selling of land."142 Indeed, private land companies were organized well before the Revolution to further the interests of land speculators in acquiring vast tracts of land. ${ }^{143}$ As is well

139. Id. at 458; see also HugHEs, supra note 91, at 124-25 (discussing impact of Parliamentary legislation on seizure of land for debt, and declaring "land was in fact becoming a pure commodity in America").

140. WoOD, supra note 35, at 128. See also MARShall Harris, Origin OF THE LAND TENuRE System IN THE United States 310 (1953) (pointing out that during the colonial era, "land was being looked upon more as a commodity to be sold for a profit and less as a family estate to be kept for posterity”); Nelson, supra note 52, at 357 (observing that land "had become a valuable commodity" in mid-seventeenth century Virginia).

141. From the seventeenth century, speculation in land was rife in colonial America. See FARNAM, supra note 31, at 32-34 ("Speculation in landed property became active in New England."); SHAW LIVERMORE, EARLY AMERICAN LAND COMPANiEs: Their INFluenCE ON CORPORATE DEVElOPMENT 27-28 (1939) (discussing land speculation in eighteenth century New England); Charles S. Grant, Land Speculation and the Settlement of Kent, 1738-1760, 28 NEw ENG. Q. 51, 54 (1955) ("Kent emphatically bears out the standard contention on the prevalence of speculation.”); John L. Harr, Land Speculation as a Theme in Southern History, 11 NORTHWEST Mo. ST. U. STUD. 1, 4-12 (1981) (discussing land speculation in southern Colonies before the Revolution).

142. Jonathan J. Bean, Marketing "the Great American Commodity": Nathaniel Massie and Land Speculation on the Ohio Frontier, 1783-1813, 103 OHIO HIST. 152, 156 (1998). See also Thomas Perkins Abernethy, From Frontier to Plantation in TENNESSEE: A STUDY IN Frontier DEMOCRACY 19 (1932) ("Speculation in lands was the most absorbing American enterprise during the later Colonial, the Revolutionary, and the early Republican periods. . . . [I]n those days, the country was run largely by speculators in real estate.”).

143. For the role of private land companies, see HARRIS, supra note 140, at 289309; ERIC HinderaKer, Elusive EMPIRES: ConstruCting COlONIALISM IN THE OHIO VALLEY, 1673-1800, at 166-69 (1997) (discussing impact of the Illinois Company and speculative activity on trans-Appalachian development schemes before the Revolution); LIVERMORE, supra note 141, at 74-132. 
known, many leaders of the Revolutionary cause were active land speculators. ${ }^{144}$ George Washington, for example, was involved in a number of speculative land ventures. ${ }^{145}$

For Americans of the eighteenth century, land speculation was much like participation in the stock market to later generations. In practice, this trading spirit superseded traditional English rules governing land ownership and transfer. The robust buying and selling of land without government intervention spoke volumes about the growing sentiment in favor of economic liberty. It is more revealing of economic attitudes than waning efforts to enforce obsolete price controls and market regulations.

\section{THE RISE OF CONTRACT}

As price controls and regulated markets declined and land speculation quickened, contracts assumed a greater role in the emerging commercial society of the late eighteenth century. In an expanding economy, merchants were more likely to trade or extend credit to persons who were strangers. Under such circumstances, transactions could not safely be grounded in trust or custom. Hence, private bargains in an impersonal market were increasingly governed by written agreements. ${ }^{146}$ Parties became accustomed to making deals and looking out for their own interests. $^{147}$ The origins of modern contract law, which developed rapidly in the nineteenth century, can be traced to this period.

Contracts constituted a legal expression of growing free market values. They provided a vehicle by which individualists could bargain for their own advantage. Contractual exchange not only promoted economic efficiency, but also underscored the autonomy of individuals.

144. For example, both James Wilson and Robert Morris were engaged in largescale land speculation. See Charles PAge Smith, JAmes Wilson: Founding Father, 1742-1798, at 159-68 (1956) ("Almost without exception the Revolutionary leaders dabbled in land.”); Ellis PAXSON OBerholtzer, ROBERT MORRIS: PATRIOT AND FINANCIER 301-13 (1903).

145. See generally Charles Royster, The Fabulous History of the Dismal SWAMP COMPANY: A STORY OF GEORgE WASHINGTON's TIMES (1999) (discussing Washington's participation in the Dismal Swamp Company, a failed speculative venture); A.M. SAKOLSKI, THE GREAT AMERICAN LAND BubBle 4-12 (1932) (discussing Washington's interest in western land).

146. Bruce H. Mann, Neighbors and Strangers: Law and Community in EARLY CONNECTICUT 34-41 (1987) (pointing out that credit transactions in early eighteenth century Connecticut were increasingly governed by written instruments); DEborah A. Rosen, Courts and Commerce: Gender, Law, and the Market ECONOMY IN COLONIAL NEW YORK 59-62, 83 (1997) (discussing increased use of contracts to govern economic relationships in eighteenth century New York); WoOD, supra note 35 , at $162-63$.

147. WoOD, supra note 35, at 162-64. 
Economic rights were the product of private bargaining, not governmental authority. To achieve these goals, the stability of contracts was essential. It was necessary that bargains be honored and not subject to subsequent interference.

Careful studies of several Colonies bear out the growing importance of contract law and a free market economy. William E. Nelson discovered that "a vibrant market economy" based on tobacco sales developed in Virginia as early as the mid-seventeenth century. ${ }^{148}$ This robust economy "gave rise to complex commercial transactions and commercial litigation."149 Nelson concluded that in Virginia by the 1640s, "the hallmark doctrine of market capitalism, that individuals should be free to enter into contracts which courts would then enforce, was firmly in place." 150

Similarly, Nelson found that the judiciary in colonial Pennsylvania wanted to encourage economic development. As he explained, the Pennsylvania Supreme Court "wanted to establish rules of law that would help entrepreneurs bring business to Pennsylvania and thereby develop its economy and bring wealth to its inhabitants."151 To achieve these goals, the colonial judges fixed clear legal rules to govern the collection of debts. In fact, courts in colonial Pennsylvania spent more time on debt collection than on any other matter. ${ }^{152}$

\section{IMPACT OF THE REVOLUTIONARY WAR}

The American Revolution produced contrary trends with respect to economic liberty. The outbreak of war with Great Britain disrupted long-settled trading patterns and sparked steep inflation. ${ }^{153}$ Colonial currency rapidly lost value. ${ }^{154}$ In this turbulent situation, a renewed regulatory impulse clashed with calls for economic freedom.

Demonstrating that old patterns of behavior die hard, state lawmakers responded to wartime economic upheaval with a program of wage and

148. Nelson, supra note 52, at 357.

149. Id. at 358 .

150. Id. at 360 .

151. William E. Nelson, Government by Judiciary: The Growth of Judicial Power in Colonial Pennsylvania, 59 SMU L. REV. 3, 35 (2006).

152. Id. at 35-37.

153. Jerome J. Nadelhaft, The Disorders of War: The Revolution in South CAROLINA 155-72 (1981).

154. Id. 
price controls reminiscent of the seventeenth century. ${ }^{155}$ As might be expected, such efforts were largely fruitless. Outspoken critics attacked wage and price controls as both unworkable and as an impairment of economic rights.

To understand these cross-currents, consider the experience of Connecticut in the Revolutionary era. During 1776, legislators passed a number of laws regulating prices and wages. ${ }^{156}$ Late that year, a convention of New England states recommended that each state in the region set a common price and wage schedule. ${ }^{157}$ In line with this recommendation, Connecticut lawmakers enacted a comprehensive measure that merits careful analysis. The law demonstrated a remarkably unsophisticated grasp of the reasons behind the price surge. It proclaimed that "the rapid and exorbitant rise upon the necessities and conveniences of life in this day of public calamity and distress is chiefly occasioned by monopolizers, the great pest of society, who prefer their own private gain to the interest and safety of their country ...."158 For good measure, the act further stated that "goods in general imported have of late owing to the unbounded avarice of some persons been sold by wholesale at the exorbitant advance of five and six hundred per cent." ${ }^{\text {"159 }}$ Having attributed wartime inflation to the greed of individuals rather than fundamental causes, the statute set the maximum daily wage for farm laborers. ${ }^{160}$ It also fixed prices for produce ranging from wheat and beef to rum and potatoes. ${ }^{161}$ There were even special schedules for goods imported from Europe. ${ }^{162}$ Violators of the wage and price regulations were subject to fines. ${ }^{163}$ As early as May of 1777 , however, lawmakers found it necessary to adjust the regulated price for many items, and to abandon controls on salt and beef. ${ }^{164}$

155. See generally MoRRIS, supra note 5, at 92-135, and Bull, supra note 67 , at 319-27, for wage and price regulations of the Revolutionary era.

156. MORRIS, supra note 5, at 93-94.

157. Id. at 94-95.

158. An Act to Prevent Monopolies and Oppression by Excessive and Unreasonable Prices of Many of the Necessaries and Conveniences of Life (1776), in 1776 ACTS AND LAWS of the State of Connecticut in America 437 (New London, Timothy Green 1776).

159. Id.

160. Id.

161. Id.

162. Id.

163. Id.

164. An Act in Addition to, and Alteration of an Act of this State, Entitled, An Act to Prevent Monopolies and Oppression by Excessive and Unreasonable Prices for Many of the Necessaries and Conveniences of Life (1777), in 1777 ACTS AND LAWS OF THE State of Connecticut in America 457, 462 (New London, Timothy Green 1777). 
Congress debated the New England price regulation scheme in the winter of 1777 and ultimately declined to endorse this program. Many in Congress doubted the practicality of price and wage regulations. ${ }^{165}$ John Adams argued that such a scheme "was tried in vain even in the absolute government of France. The high price of many Articles arises from their scarcity." 166 In New England, the controls aroused dissatisfaction and were deeply unpopular with farmers. ${ }^{167}$ By the summer of 1777, the New England states, including Connecticut, repealed the wage and price regulations. ${ }^{168}$

Advocates of regulation, however, did not give up easily. In 1778, Connecticut, joined by New York and Pennsylvania, established yet another regime of wage and price controls. ${ }^{169}$ These, too, proved shortlived. Congress, in June of 1778, recommended repeal of such regulations, reasoning, "[I]t hath been found by Experience that Limitations upon the Prices of Commodities are not only ineffectual for the Purposes proposed, but likewise productive of very evil Consequences to the Great Detriment of the public Service and greivous [sic] Oppression of Individuals.”170 Given this negative congressional attitude, Connecticut and other states promptly repealed their latest wage and price controls. ${ }^{171}$ To be sure, there were persistent efforts throughout the Revolutionary period to fix prices at the local level. ${ }^{172}$ Few modern observers are surprised that these Revolutionary attempts to legislate wages and prices were fruitless. ${ }^{173}$ American history is littered with failed efforts to set prices.

165. MORRIS, supra note 5, at 97-100.

166. Id. at 99 .

167. Id. at 101.

168. An Act for Repealing an Act, etc. (1777), in 1777 ACTS AND LAws OF THE StATE OF CONNECTICUT IN AMERICA 473, 474 (New London, Timothy Green 1777).

169. MorRIS, supra note 5, at 106. For the Pennsylvania Statute of 1778, see Bull, supra note 67, at 322-23 (pointing out that the Act was suspended and eventually repealed without having ever gone into effect). It is noteworthy that Massachusetts did not join in this effort, and did not enact any additional statewide law fixing wages and prices for the remainder of the Revolutionary era. Id. at 322.

170. 11 JOURNALS OF THE CONTINENTAL CONGRESS, 1774-1789, at 569 (Worthington Chauncey Ford ed., 1908), available at http://memory.loc.gov/ammem/amlaw/lwjc.html.

171. MORRIS, supra note 5, at 107.

172. Id. at 109-17. See also Andrew McFarland Davis, The Limitation of Prices in Massachusetts 1776-1779, in 10 PubliCATIONS OF THE COLONIAL SOCIETY OF MASSACHUSETTS 119 (1907).

173. FRIEDMAN, supra note 12, at 43 (observing that wage and price regulations were "briefly and ineffectively revived during the Revolutionary War, as an emergency measure”). 
What is significant, however, is that arguments against such regulations were often couched in terms of economic liberty. A 1777 writer asserted that price fixing "always has and ever will be impracticable in a free country, because no law can be framed to limit a man in the purchase or disposal of property, but what must infringe those principles of liberty for which we are gloriously fighting." ${ }^{174}$ In 1778, John Witherspoon insisted that "[f]ixing Prices by Law never had nor ever will have any Effect but stopping Commerce and making Things scarce and dear."175 A year later a number of Philadelphians petitioned the city to end price controls, insisting that such regulations infringed the rights of property owners by preventing the sale of goods in an open market. ${ }^{176}$

In the same vein, Gouverneur Morris, later a member of the Constitutional Convention, assailed Pennsylvania's Revolutionary era price controls. He argued that such regulations were not only foolish as a matter of economic policy but also amounted to an invasion of property rights. ${ }^{177}$ The regulation of prices, he asserted, "gave a woeful impression of the new governments, by laying down a violation of the rights of property as the corner stone on which they were to be erected."

The Pennsylvania Constitution contained a unique provision requiring that a Council of Censors be elected every seven years. The duty of this body was to report whether the Constitution had been preserved. Invoking the Pennsylvania Bill of Rights that guaranteed "a right to be protected in the enjoyment of life, liberty and property," the Council found in 1784 that market and price regulations were unconstitutional. Specifically, the Council declared:

Some of the acts of assembly, made to prevent forestalling, were also unconstitutional invasions of the rights of property.

$\ldots$

It is the opinion of this committee, that the attempts which have been made to regulate the prices of commodities, were absurd and impossible. They tended to produce the very opposite effects to those which they were designed to produce, and were invasions of the right of property. ${ }^{179}$

174. Letter to the Editor, Conn. Courant, May 12, 1777, at 1.

175. Letter from John Witherspoon to William Churchill Houston (Jan. 27, 1778),

in 3 LetTers of MEMBERS OF THE CONTINENTAL CONGRESS 57 (Edmund C. Burnett ed., 1926).

176. MORRIS, supra note 5, at 117.

177. Jennifer Nedelsky, Private Property AND the Limits of American CONSTITUTIONALISM: THE MADISONIAN FRAMEWORK AND ITS LEGACY 72-74 (1990). For the role of Gouverneur Morris in drafting the Constitution, see generally RICHARD Brookhiser, Gentleman ReVolutionary: Gouverneur Morris-The RaKe Who WROTE THE CONSTITUTION (2003).

178. Letter from an American, To the Inhabitants of America, PA. PACKET, Mar. 23, 1780 , at 2 .

179. The Proceedings Relative to Calling the Conventions of 1776 And 1790, 
By 1783, then, the property clause of the Pennsylvania Bill of Rights was construed to affirm the right of owners to sell their goods at market prices.

I make no claim that Americans of the Revolutionary era were of one mind in rejecting wage and price regulations. Clearly the public was divided and advocates of regulations were persistent. By the same token, opponents of regulation gained the upper hand by weaving together practical objections and constitutional arguments grounded in economic liberty. Moreover, the debate over wartime controls had a lasting consequence. One result, according to Richard B. Morris, was "the crystallization of sentiment" among members of the Constitutional Convention of 1787 "in favor of laissez faire policies in the internal economic life of the nation." 180 Moreover, opposition to wage and price controls was increasingly framed in terms of constitutionally protected rights. In the aftermath of the American Revolution, the distinguished treatise writer Thomas M. Cooley observed in 1878, "it has been commonly supposed that a general power in the State to regulate prices was inconsistent with constitutional liberty."

The dispute over wage and price controls in the Revolutionary period lends support to the thesis that Americans of the late eighteenth century were increasingly receptive to ideas of economic liberty, but even more compelling evidence can be found in early state constitutions. The influential Virginia Bill of Rights of 1776, for instance, declared that all men "have certain inherent rights . . . ; namely, the enjoyment of life and liberty, with the means of acquiring and possessing property, and pursuing and obtaining happiness and safety."182 Likewise, the New Hampshire Constitution of 1784 stated: "All men have certain natural, essential, and inherent rights; among which are-the enjoying and defending life and liberty-acquiring, possessing and protecting property—and in a

at 87, 113 (Harrisburg, Pa., John S. Wiestling 1825).

180. MORRIS, supra note 5, at 118.

181. Thomas M. Cooley, Treatise on the Constitutional Limitations Which Rest Upon the Legislative POWER of the States OF the AMERICAN Union 742 (4th ed. 1878).

182. VA. CONST. of 1776, Bill of Rights, $\S 1$, reprinted in 7 THE FEDERAL AND State Constitutions, Colonial Charters, and Other ORGanic LaWs of THE

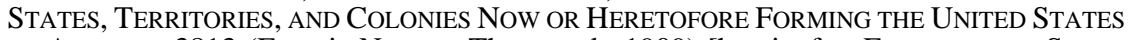
OF AMERICA 3813 (Francis Newton Thorpe ed., 1909) [hereinafter FEDERAL AND STATE CONSTITUTIONS]. 
word, of seeking and obtaining happiness.”" ${ }^{\text {"183 }}$ Similar language asserting the right to acquire property appeared in several other early state constitutions, including constitutions in Massachusetts and Pennsylvania. ${ }^{184}$ Such provisions did more than just secure existing property arrangements; they guaranteed the right to obtain property. Right-to-acquire language held out the promise of economic opportunity for all persons. ${ }^{185}$

As further evidence of this commitment to economic liberty, states took steps to discourage undue concentration of wealth. The abolition of primogeniture and entail has already been considered. Several state constitutions also prohibited grants of monopoly. The North Carolina Constitution of 1776, for example, proclaimed that monopolies "are contrary to the genius of a free State and ought not to be allowed."186 Along the same line, four state conventions that ratified the proposed Federal Constitution urged an amendment barring monopolies. This aversion to grants of special economic privilege underscored the broad based support for economic liberty. ${ }^{187}$

\section{THE ConTRACT Clause}

It remains to link the growing free market ideology to the framing of the United States Constitution. The delegates to the Philadelphia Convention were to a large degree prompted by the desire to bring about a greater protection of economic rights. ${ }^{188}$ Yet for the most part, notwithstanding their dedication to the rights of property owners, the Framers initially relied on institutional and political arrangements to safeguard individual rights. ${ }^{189}$ The basic constitutional scheme was to

183. N.H. Const. of 1784, pt. I, art. II, reprinted in 4 FEDERAL AND STATE Constitutions, supra note 182, at 2453-54.

184. James W. Ely, Jr., "To Pursue Any Lawful Trade or Avocation": The Evolution of Unenumerated Economic Rights in the Nineteenth Century, 8 U. PA. J. CONST. L. 917, 918-19 (2006).

185. Id. See also FARNAM, supra note 31, at 124-25:

The general presumption of the bills of rights in the early constitutions and in the first eight amendments to the Federal Constitution was in favor of the liberty of the individual, and the protection of his property rights against arbitrary power on the part of the government. This in turn created a presumption in favor of personal freedom against the subordination of human rights to property rights. It also created a presumption in favor of equality of Id. opportunity.

186. N.C. CONST. of 1776, Declaration of Rights, $\S$ XXIII, reprinted in 5 FEDERAL AND STATE CONSTITUTIONS, supra note 182, at 2788.

187. Ely, supra note 184, at 931.

188. GotTfried Dietze, America's Political Dilemma: From Limited to UNLIMITED DEMOCRACY 66 (1968).

189. Wayne McCormack, Lochner, Liberty, Property, and Human Rights, 1 N.Y.U. J.L. \& LiBERTY 432, 451 (2005) ("The original draftsmen focused on the structure of 
protect personal and economic liberty through elaborate procedural devices-notably, the separation of powers among the branches of the federal government. ${ }^{190}$ Still, many provisions of the original Constitution pertain to economic interests. ${ }^{191}$ A number of these restricted the power of the states, whose excesses had done much to trigger the call for a new national government. ${ }^{192}$ The most important of these provisions for our purpose was the Contract Clause. ${ }^{193}$ This Clause best exemplifies the Framers' commitment to economic liberty and warrants a brief exploration.

To trace the origins of the Contract Clause, we must start by considering the troubled economic circumstances of post-Revolutionary America. Attaining independence caused much economic dislocation. ${ }^{194}$ It ended the trade restrictions imposed by the English Navigation Acts, but also brought about the loss of markets with Great Britain and its other colonies. The Revolution, moreover, generated wholesale interference with economic arrangements by state legislatures. Responding to depressed economic conditions following independence, state lawmakers enacted a host of debt-relief laws designed to help debtors at the expense of creditors. ${ }^{195}$ Such measures included stays on the collection of debts, laws allowing the payment of debts in installments, and statutes authorizing the payment of obligations in commodities. ${ }^{196}$ State lawmakers also issued quantities of paper money, and made such paper currency legal tender for the payment of debts. ${ }^{197}$ These laws not only discouraged commerce by frustrating the enforcement of contracts but portended threats to the security of property generally. As Chief Justice John Marshall recalled,

The power of changing the relative situation of debtor and creditor, of interfering with contracts, a power which comes home to every man, touches the interest of all, and controls the conduct of every individual in those things

government out of a belief that diffusion of power among different organs would obviate the need for specific guarantees of individual rights.”).

190. Gordon S. WoOd, The Creation OF the AMERICAN Republic, 1776-1787, at 150-61, 547-62 (1998).

191. ELY, supra note 1, at 43-46.

192. Id. at 45 .

193. U.S. Const. art. I, $\S 10$, cl. 1 provides in part: "No State shall . . pass any ...

Law impairing the obligation of Contracts ....”

194. Bruchey, supra note 2, at 1138-39.

195. NADELHAFT, supra note 153.

196. Id.

197. Id.; Allan Nevins, The American States During and After the Revolution, 1775-1789, at 404-05, 537, 571 (1924). 
which he supposes to be proper for his own exclusive management, had been used to such an excess by the state legislatures, as to break in upon the ordinary intercourse of society, and destroy all confidence between man and man. This mischief had become so great, so alarming, as not only to impair commercial intercourse, and threaten the existence of credit, but to sap the morals of the people, and destroy the sanctity of private faith. To guard against the continuance of the evil, was an object of deep interest with all the truly wise, as well as the virtuous, of this great community, and was one of the important benefits expected from a reform of the government. 198

In short, the bitter post-Revolutionary experience convinced many political leaders that state protection of contractual rights was inadequate. ${ }^{199}$

The forerunner of the Contract Clause can be found in the Northwest Ordinance of $1787 .^{200}$ The Confederation Congress enacted the Ordinance in July of that year to provide territorial governance for the area of the Old Northwest. Articulating a number of fundamental principles, the Ordinance had much of the character of a constitutional document. ${ }^{201}$ The Ordinance contained several important provisions regarding the rights of property owners, including one ensuring the sanctity of private contracts. Article 2 of the Ordinance stated:

And, in the just preservation of rights and property, it is understood and declared, that no law ought ever to be made or have force in the said territory, that shall, in any manner whatever, interfere with or affect private contracts, or engagements, bona fide, and without fraud previously formed. ${ }^{202}$

This language was evidently inserted as part of a larger scheme to encourage economic development in the largely unsettled territories. Viewed in this light, the protection of agreements was a crucial step in attracting eastern investors. ${ }^{203}$ The territorial government was prevented from abridging private economic deals, creating a hospitable climate for outside capital.

198. Ogden v. Saunders, 27 U.S. (12 Wheat.) 213, 354-55 (1827) (Marshall, C.J., dissenting).

199. Priest, supra note 132, at 397 ("Fear of the consequences of such democratically enacted policies was one of the reasons for including the Contracts Clause in the United States Constitution, as a means for the federal courts to regulate state legislatures' debt relief measures.”).

200. James W. Ely, Jr., The Marshall Court and Property Rights: A Reappraisal, 33 J. Marshall L. ReV. 1023, 1030-31 (2000).

201. See Denis P. Duffey, Note, The Northwest Ordinance as a Constitutional Document, 95 Colum. L. REV. 929 (1995).

202. Northwest Ordinance of 1787, art. 2, reprinted in 32 JouRnALs OF THE Continental Congress, 1774-1789, at 340 (R. Hill ed., 1936), available at http://memory.loc.gov/ammem/amlaw/lwjc.html.

203. Andrew R.L. Cayton, The Northwest Ordinance from the Perspective of the Frontier, in The Northwest ORDinANCE 1787: A BicENTENNIAL HANDBOOK 1, 8-10 (Robert M. Taylor, Jr. ed., 1987); Duffey, supra note 201, at 938, 960. 
Congress enacted the Northwest Ordinance while the Constitutional Convention was meeting in Philadelphia. ${ }^{204}$ In August of 1787, the delegates were considering constitutional limitations on the power of the states. Rufus King of Massachusetts moved to insert into the Constitution "in the words used in the Ordinance of [Congress] establishing new States, a prohibition on the States to interfere in private contracts."205 Both the process by which the Contract Clause was adopted as part of the Constitution and the intended scope of the Clause have been the subject of extensive historical inquiry. ${ }^{206}$ It is not my purpose to enter that debate here. There was surprisingly little discussion of the Contract Clause by the delegates at the Convention given its subsequent significance in American constitutionalism. ${ }^{207}$ The evidence shows that the immediate impetus for the Clause was to curb state debtor relief measures that undercut the sanctity of contracts and threatened credit relationships. ${ }^{208}$ At the very least, the Framers clearly wished to assure the

204. Duffey, supra note 201, at 929-30.

205. 2 The Records of the Federal Convention of 1787, at 439 (Max Farrand ed., rev. ed. 1937).

206. The classic, if dated, history of the Contract Clause is Benjamin FletCher Wright, JR., The Contract Clause OF THE CONSTITUTION (1938). For helpful recent studies, see Steven R. Boyd, The Contract Clause and the Evolution of American Federalism, 1789-1815, 44 WM. \& MARY Q. 529 (1987) and James W. Ely, Jr., Origins and Development of the Contract Clause (Apr. 8, 2005) (unpublished manuscript), available at http://ssrn.com/abstract=839904). Scholars have long debated whether the Contract Clause was expected to apply only to private agreements or to public contracts by state governments as well. Compare Ely, supra note 200, at 1029-33 (contending that the Marshall Court's application of the Contract Clause to public as well as private agreements was consistent with both the purpose and language of the clause), and Douglas W. Kmiec \& John O. McGinnis, The Contract Clause: A Return to the Original Understanding, 14 HASTINGS CONST. L.Q. 525, 539 n.67 (1987) (“A distinction between public and private contracts is unwarranted in view of the lack of language limiting the application of the Clause to private contracts or similarly limiting discussion at the Convention.”), with WRIGHT, supra, at 31-32 (illustrating how the Marshall Court expanded application of the Contract Clause beyond objectives of the Framers), and Thomas W. Merrill, Public Contracts, Private Contracts, and the Transformation of the Constitutional Order, 37 CASE W. RES. L. REv. 597, 600 (1987) (arguing that a strong case can be made that the Contract Clause "was not thought to impose a general duty on state governments to honor their own obligations").

207. WRIGHT, supra note 206, at 9-10.

208. Richard A. Epstein, Toward a Revitalization of the Contract Clause, $51 \mathrm{U}$. CHI. L. REV. 703, 72 (1984) (pointing out that the debtor-creditor relationship "was one leading concern of the [F]ramers in drafting the clause”). 
stability of contractual arrangements by preventing state abridgements of contracts. $^{209}$

It is revealing that the Framers saw contractual rights as sufficiently important to warrant a specific ban on state impairment. By the time of the Philadelphia Convention, contracts were widely seen as a vital aspect of economic liberty. ${ }^{210}$ Interference with contracts amounted to an attack on private economic ordering. In addition, contracts also represented an increasingly significant type of commercial wealth. ${ }^{211}$

Just as the Framers of the Federal Constitution drew upon the Northwest Ordinance, so the Federal Constitution and Bill of Rights became an influential model for later state constitutions. In particular, many states adopted provisions designed to safeguard the security of contracts. When Pennsylvania and South Carolina revised their fundamental laws in 1790, they added a contract clause. Thus, the Pennsylvania Constitution stated "[t]hat no ex post facto law, nor any law impairing contracts, shall be made." ${ }^{212}$ A large number of the constitutions of the newer states followed suit. The Kentucky Constitution (1792), the Tennessee Constitution (1796), the Louisiana Constitution (1812), the Mississippi Constitution (1817), the Illinois Constitution (1818), the Alabama Constitution (1819), the Missouri Constitution (1820), the Michigan Constitution (1835), and the Florida Constitution (1838) all contained a clause barring the impairment of contracts. In addition, the Virginia Constitution, as revised in 1830, included a contract clause. Although not all states in the antebellum era adopted a contract clause, enough did to reinforce the high standing of contractual rights in the constitutional order.

209. Kmiec \& McGinnis, supra note 206, at 534 ("[T] he history of the Clause suggests that it was aimed at all retrospective, redistributive schemes in violation of vested contractual rights, of which debtor relief was merely a prime example.”).

210. Bruce Ackerman, Constitutional Politics/Constitutional Law, 99 YALE L.J. 453, 537 (1989).

This was the Federalist effort to link the eighteenth century's affirmation of individual liberty with the rhetoric of contract and private property. Thus, the Federalists valued market "freedom" so highly that they forbade the states from "impairing the obligation of Contract" in the original 1787 Constitution, at a Id. time when they believed an elaborate Bill of Rights unnecessary.

211. See HugHES, supra note 91, at 122-23 (stressing the importance of contracts in colonial business transactions); Nelson, supra note 52, at 357-58 (discussing litigation over contracts dealing with land, commodities, and servants).

212. Pa. Const. of 1790, art. IX, $\S 17$, reprinted in 5 Federal and State Constitutions, supra note 182, at 3101. 


\section{EMERgING CONSTITUTIONAL ThOUGHT}

Evidence of the Framers' thinking with respect to economic liberty can be derived from the policies that colonial and state governments pursued in the late eighteenth century. Developments in the legal culture were moving unmistakably, albeit unevenly, toward a freer economy. The decline of mercantilism, the withering of wage and price controls, the pervasive land speculation, the overthrow of the English navigational system, and the rise of contracting all pointed toward a new economic and legal order. No doubt the Framers were familiar with these trends and most likely approved of them. These economic liberty tendencies informed the constitution-making process and dovetailed with deep tenets of Anglo-American constitutional thought.

Leading political figures of the founding generation drew upon currents of constitutional theory and economic philosophy in England. English political theorist John Locke had an enormous impact on the American concept of constitutionalism. ${ }^{213}$ A proponent of natural law and representative government, Locke famously insisted that the very purpose of government was the preservation of "lives, liberties, and estates." ${ }^{214}$ It is difficult to overestimate Locke's influence. "By the late eighteenth century,” Pauline Maier has cogently noted, “'Lockean' ideas on government and revolution were accepted everywhere in America; they seemed, in fact, a statement of principles built into English constitutional tradition.”215 It followed that the Framers generally adhered to the Lockean notion that individual property ownership was a natural right with which government had only limited power to interfere.

The ideas of the Scottish political economist Adam Smith, whose landmark treatise, An Inquiry Into the Nature and Causes of the Wealth of Nations, was published in 1776, also had a strong appeal to Americans. ${ }^{216}$ A champion of entrepreneurial freedom and the market

213. Ellen Frankel Paul, Freedom of Contract and the "Political Economy" of Lochner v. New York, 1 N.Y.U. J.L. \& LIBERTY 515, 528-37 (2005) (discussing influence of Locke on drafting the U.S. Constitution and state constitutions of the Revolutionary era).

214. John Locke, Two Treatises of Government 178 (Mark Goldie ed., J.M. Dent 2000) (1690).

215. Pauline Maier, American Scripture: Making the Declaration of INDEPENDENCE 87 (1997).

216. James L. Huston, Securing the Fruits of Labor: The American ConCEPT OF WEALTh DisTRIBUTION, 1775-1900, at 69-75 (1998) (discussing the affinity between Smith and American Revolutionary leaders). 
economy, Smith urged minimal governmental oversight of economic activity. He stressed the self-adjusting nature of a free-market economy. ${ }^{217}$ "Smith and his successors," one scholar has observed, "explained how the 'invisible hand' of self-interest in the marketplace produced general well-being in the economy and augmented national wealth."218 Smith's assault on mercantilism did much to hasten its decay. ${ }^{219}$ Although neither the Framers nor the general public embraced a strict laissez-faire policy sometimes associated with Smith, the new nation had largely a free market economy grounded on economic liberty.

Important members of the founding generation underscored this commitment to economic freedom. James Madison, for instance, commented at length on the relationship between property ownership, the economy, and the Constitution. In the famous tenth essay in The Federalist, he maintained that extending the sphere of the proposed new national government would prevent any interest group from gaining control and invading the rights of others. "[A] rage for paper money, for an abolition of debts, for an equal division of property, or for any other improper or wicked project," Madison declared, "will be less apt to pervade the whole body of the Union, than a particular member of it . ..."220 For purposes of this article, Madison's theory of broad representation as a way to diffuse interest group pressure is less important than his strong disapproval of contractual interference and property redistribution by government, both described as "improper and wicked." Madison regarded redistributive schemes as not only foolish policy but also as violative of liberty. He was especially concerned about interferences with contractual transactions because they were less apparent than outright confiscation and were therefore more dangerous. To make his views more explicit, Madison stated that "laws impairing the obligation of contracts, are contrary to the first principles of the social compact, and to every principle of sound

217. Bernard H. Siegan, ECONOMic Liberties AND the Constitution 193 (2d ed. 2006).

218. Huston, supra note 216, at 69-70.

219. Lars G. Magnusson, Mercantilism, in A COMPANION TO THE HistoRy OF Economic ThOught 47 (Warren J. Samuels et al. eds., 2003) (analyzing Smith's critique of the mercantile system); William D. Grampp, The Liberal Elements in English Mercantilism, 66 Q.J. ECON. 465, 465 (1952):

It is also customary to describe mercantilism as the antithesis of liberal, or classical, economic doctrine. Adam Smith used some of his strongest invective against it, and since his time mercantilism has been thoroughly condemned by liberal economists because its practices were the very kind of interference which they always have regarded as useless, unwise, or mischievous.

220. The Federalist No. 10, at 49 (James Madison) (Buccaneer Books 1992). 
legislation."221 He pictured the Contract Clause as a "bulwark in favor of personal security and private rights."222

As a member of the first Congress, Madison took the lead in formulating the Bill of Rights. ${ }^{223}$ He included protection for the rights of property owners in his proposals, and two important guarantees were incorporated in the Fifth Amendment, along with procedural safeguards for criminal trials. ${ }^{224}$ The Fifth Amendment explicitly reflected the Lockean view that protection of property was a chief aim of government. Madison thought of property as imposing a limit on the power of government, thereby allowing a large area for private economic ordering.

Madison's commitment to economic liberty was underscored in his famous 1792 essay, Property. ${ }^{225}$ Here, Madison broadly defined property to encompass freedom of expression and religious liberty as well as possessions. ${ }^{226}$ Reflecting his aversion to special economic privileges, he stressed the right of individuals to follow vocations of their choice:

That is not a just government, nor is property secure under it, where arbitrary restrictions, exemptions, and monopolies deny to part of its citizens that free use of their faculties, and free choice of their occupations, which not only constitute their property in the general sense of the word; but are the means of acquiring property strictly so called. What must be the spirit of legislation where a manufacturer of linen cloth is forbidden to bury his own child in a linen shroud, in order to favour his neighbour who manufactures woolen cloth; where the manufacturer and wearer of woolen cloth are again forbidden the oeconomical [sic] use of buttons of that material, in favor of the manufacturer of buttons of other materials!227

As this suggests, Madison saw one's ability to acquire property as an inherent aspect of personal liberty. ${ }^{228}$ To restrict the right to acquire property was in effect to limit individual liberty. According to Jennifer Nedelsky, Madison believed that government should "ensure the free

221. The Federalist No. 44 (James Madison), id., at 227.

222. Id.

223. ELY, supra note 1, at 53-54.

224. The Fifth Amendment provides in part that no person shall be "deprived of life, liberty, or property, without due process of law; nor shall private property be taken for public use, without just compensation.” U.S. CONST. amend. V.

225. James Madison, Property, NATIONAL GAZETTE, Mar. 29, 1792, reprinted in 1 The Founders' CONSTITUTION 598, 598-99 (Philip B. Kurland \& Ralph Lerner eds., 1987).

226. Id. at 598 .

227. Id. at 598-99.

228. See NEDELSKY, supra note 177, at 29-30 (stressing Madison's endorsement of the right to acquire property). 
exercise of the faculties of acquisition by preventing unwarranted or discriminatory restrictions on this freedom." 229 Government, in other words, was not just to protect the existing rights of owners but to preserve opportunity.

This is not to say that Madison ruled out all governmental regulations of property. He left room for the states to promote and control economic behavior, but he opposed both monopoly privilege and redistributive schemes that helped some at the expense of others. ${ }^{230}$

There is no way to determine the extent to which Madison's views were representative of the Framers as a whole. But considering his key role in drafting the Constitution and Bill of Rights, it is appropriate to give special weight to his understanding of economic rights. Madison, moreover, left a lasting imprint on American constitutionalism. As Nedelsky observed,

[T] he notion that property and contract were essential ingredients of the liberty the Constitution was to protect, was common to Madison, Marshall, and the twentieth-century advocates of laissez-faire. And the idea that property and contract could define the legitimate scope of governmental power was a basic component of constitutionalism from 1787 to $1937 .{ }^{231}$

Certainly, Alexander Hamilton shared Madison's distaste for legislative abridgement of contractual rights. Seen by some historians as the author of the Contract Clause, Hamilton pictured laws abridging contractual obligations as "atrocious breaches of moral obligation and social justice."232 He stressed the utilitarian role of contracts in commercial life. In The Federalist, for example, Hamilton stated: "Laws in violation of private contracts . . . amount to aggressions on the rights of those States, whose citizens are injured by them ...."233 In his mind, state laws impairing contracts would negatively impact the flow of commerce among the states. Speaking of the various restrictions on state power in Article 10, Section 10 of the Constitution, Hamilton hailed "the precautions against the repetition of those practices on the part of the state governments, which have undermined the foundations of property and credit . . ..”234 Following ratification of the Constitution, Hamilton urged a broad

229. Id. at 29.

230. SIEGAN, supra note 217, at 59-60; ELY, supra note 1, at 49-50, 56.

231. NEDELSKY, supra note 177 , at 228.

232. The Federalist No. 7, at 43 (Alexander Hamilton) (Jacob E. Cooke ed., 1961).

233. Id. at 42

234. The Federalist No. 85 (Alexander Hamilton), id., at 588. 
reading of the Contract Clause to encompass state legislation impairing a state's own obligations. $^{235}$

Hamilton was not an adherent of a laissez-faire philosophy. As Secretary of the Treasury, he proposed an ambitious program of protective tariffs and subsidies to encourage economic growth. ${ }^{236}$ He also successfully recommended that Congress charter a national bank-a hybrid institution largely under private control— to stabilize the currency. ${ }^{237}$ Yet Hamilton was familiar with the work of Adam Smith and was a forceful supporter of a market economy based on private property and security of contracts. ${ }^{238}$ Although he saw room for government to promote business, he declared in 1801, "In matters of industry, human enterprise ought, doubtless, to be left free in the main, not fettered by too much regulation."239

Other evidence of the likely intention of the Framers is provided by James Wilson. He had been heavily involved in the controversy over the repeal of the charter of the Bank of North America. ${ }^{240}$ In 1785, at the behest of radicals and agrarians, the Pennsylvania legislature revoked the charter of the bank. ${ }^{241}$ Wilson argued at length against this step, likening the charter to a contract. ${ }^{242}$ He maintained that state legislatures could not abridge contracts. As Nedelsky noted: "Not only did [Wilson] think that upholding contracts was extremely important economically, he saw the obligation of contract as part of the fundamental obligation to fulfill promises which makes society possible."243

235. 4 The Law Practice of Alexander Hamilton 430-31 (Julius Goebel, Jr. \& Joseph H. Smith eds., 1980). See generally C. PETER MAGRATH, YAZOO: LAW AND Politics IN THE New RePUBlic 21-30 (1966) (analyzing Hamilton's argument that the Contract Clause prevented a state from breaking its contractual arrangement).

236. Peter McNamara, Political Economy and Statesmanship: SMith, HAMILTON, AND THE FOUNDATION OF THE COMMERCIAL REPUBlic 128-39 (1998).

237. Id. at 124-28.

238. Characterizing Hamilton as the "chief agent of a market economy," a recent biographer has declared: "Hamilton did not create America's market economy so much as foster the cultural and legal setting in which it flourished.” RON CHERNOW, AleXANDER Hamilton 345 (2004).

239. Alexander Hamilton, The Examination No. 3 (Dec. 24, 1801), in 25 THE Papers of AleXander Hamilton 467 (Harold C. Syrett ed., 1977).

240. SMITH, supra note 144, at 146, 150-53.

241. Id. at $148-55$.

242. Id. at 152-53; Ely, supra note 206, at 15-18.

243. NEDELSKY, supra note 177, at 299 n.141. 


\section{CONCLUSION}

The economic values embraced by the Constitution and Bill of Rights are hotly contested. ${ }^{244}$ Is the principle of economic liberty built into the Constitution and Bill of Rights - and to what extent —or is the Constitution simply neutral regarding economic issues? It bears emphasis that there was a consensus among the Framers that property and contractual rights should be protected. ${ }^{245}$ These were seen as essential to achieve both political liberty and the advantages of a market economy. The Framers crafted the provisions in the Constitution and Bill of Rights to guarantee economic rights.

The historical record stops short of establishing that the Framers expected the Constitution to embody a particular theory, such as laissezfaire, but it does not follow that the Constitution was entirely neutral with respect to economic rights. Property and contractual rights were assigned a high value by the Framers, and were protected by language in the Constitution and Bill of Rights. Legislators were free to fashion economic policy so long as they respected these bedrock rights. Lawmakers, therefore, did not have carte blanche to devise policies that infringed property and contractual rights. Although there is room to debate-as people did at the time of the founding - which legislative acts and regulations violate such rights, one can fairly conclude that the Framers envisioned a substantially free market economy with a large measure of economic liberty for individuals to pursue their own interest. "Federalists proposed, in sum," Kermit L. Hall and Peter Karsten cogently observe, "to place the new land in the mainstream of acquisitive capitalism." 246 Moreover, as Joyce Appleby reminds us, the ascendancy of a market culture following the Revolution "took place in the United States under circumstances that forged a powerful link between political and economic freedom."247

244. Compare Siegan, supra note 3 (maintaining that the Framers anticipated a protective constitutional framework for property), with William Letwin, The Economic Policy of the Constitution, in LIBERTY, PROPERTY, AND THE FOUNDATIONS OF THE AMERICAN Constitution 121-39 (Ellen Frankel Paul \& Howard Dickman eds., 1989) (insisting that the Framers assumed private ownership of property but did not embody any particular economic policy in the Constitution).

245. Bruchey, supra note 2, at 1136.

246. HALL \& KARSTEN, supra note 22, at 72.

247. Joyce Appleby, InHeriting the Revolution: The First Generation of AMERICANS 56 (2000). 